\title{
MENINGKATKAN KETERAMPILAN MOTORIK HALUS ANAK MELALUI KEGIATAN MENJAHIT DI KELOMPOK B TK ISLAM KEMARAYA KENDARI
}

\author{
Rosnawati Ranau $^{1)} *$, Safiudin Saranani ${ }^{2)}$ \\ ${ }^{1}$ Alumni Jurusan PG-PAUD, Universitas Halu Oleo. Jln. H.E.A Mokodompit, Kendari 93232, \\ Indonesia. \\ ${ }^{2}$ Dosen Jurusan PG-PAUD, Universitas Halu Oleo. Jln. H.E.A Mokodompit, Kendari 93232, \\ Indonesia.
}

Korespondensi Penulis. Email: rosnawatikendari2017@ gmail.com/085363246815

\begin{abstract}
Abstrak
Penelitian ini bertujuan untuk meningkatkan keterampilan motorik halus anak melalui kegiatan menjahit di Kelompok B TK Islam Kemaraya Kendari. Subjek dalam penelitian ini adalah guru dan anak didik yang berjumlah 14 orang yang terdiri atas 5 orang anak perempuan dan 9 orang anak lakilaki. Jenis penelitian ini adalah penelitian tindakan kelas yang dilaksanakan dalam dua siklus. Pengumpulan data dalam penelitian ini menggunakan metode observasi, wawancara dan dokumentasi. Berdasarkan analisis data hasil observasi aktivitas mengajar guru pada siklus I diperoleh persentase ketercapaian sebesar $68,75 \%$, aktivitas belajar anak didik diperoleh persentase ketercapaian sebesar $60 \%$ sedangkan hasil belajar anak berupa peningkatan keterampilan motorik halus melalui kegiatan menjahit sebelum dilakukan tindakan sebesar 35,71\% anak memperoleh nilai BSB dan BSH kemudian meningkat pada siklus I sebesar 64,29\%. Pada siklus II, persentase ketercapaian aktivitas mengajar guru mengalami peningkatan menjadi $87,5 \%$, persentase ketercapaian aktivitas belajar anak didik juga mengalami peningkatan menjadi $86,67 \%$ dan hasil belajar anak berupa peningkatan keterampilan motorik halus melalui kegiatan menjahit meningkat sebesar $85,71 \%$.
\end{abstract}

Kata kunci: Keterampilan, Motorik Halus, Kegiatan Menjahit

\section{IMPROVING CHILDREN'S FINE MOTORIC SKILL THROUGHT SEWING ACTIVITY IN GROUP B TK ISLAM KEMARAYA KENDARI}

\begin{abstract}
This Research aims to improve the children's fine motoric skill through sewingactivity in Group $B$ TK Islam Kemaraya Kendari. The subject in this study is the teacher and children which amounted of 14 people comprising 5 girls and 9 boys by range age 5-6 years. This type of research is a classroom action research which conducted in two cycles. The collection of data in this study using observation, interview and documentation. Based on the results of observation data analysis of teacher teaching activity in cycle I retrieved percentage of $68.75 \%$, the learning activities students obtained the percentage of $60 \%$ whereas the results of learning in the form of fine motoric skill through the sewing activity the action by $35.71 \%$ children scored BSB and BSH then improved in the cycle I of $64.29 \%$. In the cycle II, the percentage of teachers teaching activity have elevated into a $87.5 \%$, the percentage of learning activities students also increased being $86.67 \%$ and child study results in the form of increased fine motoric skill through the sewing activity increased by $85.71 \%$.
\end{abstract}

Keywords: Skill, Fine Motoric, Sewing Activit.

\section{PENDAHULUAN}

Pendidikan anak usia dini adalah suatu upaya pembinaan yang ditujukan bagi anak sejak lahir sampai dengan usia enam tahun yang dilakukan melalui pemberian rangsangan pendidikan untuk membantu pertumbuhan dan perkembangan jasmani dan rohani agar anak memiliki kesiapan dalam memasuki pendidikan lebih lanjut (Direktorat PAUD, 2004: 1). Pendidikan pada masa usia dini merupakan wahana pendidikan yang sangat fundamental 
dalam memberikan serta mengarahkan kemampuan diri anak untuk memperoleh penguasaan atas sesuatu yang baru.

Salah satu aspek penting dalam perkembangan anak usia dini adalah aspek keterampilan motorik halus. Motorik adalah kemampuan dan aktivitas yang berkaitan dengan gerak tubuh dengan otot-otonya (Lenny Fanggideraj, 1995:177).

Motorik adalah bentuk perilaku gerak manusia. Keterampilan motorik halus diperlukan oleh anak sejak dini dalam rangka mengembangkan koordinasi mata dan tangan. Susanto (Viliani Rosi, 2014: 2) menjelaskan bahwa motorik halus adalah gerakan halus yang melibatkan bagian tertentu saja yang dilakukan oleh oto-otot kecil saja. Sedangkan Sunardi dan Sunaryo (2007) mengemukakan bahwa motorik halus adalah gerakan yang menggunakan sebagian anggota tubuh tertentu dan dipergunakan untuk memanipulasi lingkungan.

Kartini Kartono (1998: 97) motorik halus adalah ketangkasan atau keterampilan tangan, jari-jari serta pergelangan tangan serta penguasaan terhadap otot-otot dan urat wajah. Motorik halus adalah gerakan yang melibatkan bagian-bagian tertentu yang dilakukan oleh otototot kecil serta memerlukan koordinasi yang cermat (Depdiknas, 2008: 10). Djamaris (2006: 7) mengemukakan bahwa keterampilan motorik halus anak usia taman kanak-kanak ditekankan pada koordinasi gerakan motorik halus, dalam hal ini berkaitan dengan kegiatan meletakkan atau memegang suatu objek dengan menggunakan jari tangan.

Syamsu \& Nani (2016: 60) menerangkan bahwa perkembangan motorik halus anak usia dini ditandai dengan gerak atau aktivitas motorik yang lincah. Adapun aktivitas tersebut adalah: (a) menulis, (b) menggambar atau melukis, (c) mengetik (komputer), (d) Merupa (seperti membuat kerajinan dari tanah liat), (e) Menjahit, dan (e) membuat kerajinan dari kertas

Keterampilan motorik halus anak merupakan keterampilan yang sangat penting untuk distimulasi sejak dini, yaitu sejak usia prasekolah. Tujuan meningkatkan motorik halus menurut Sumantri (2005: 146) adalah: (a) Mampu mengembangkan kemampuan motorik halus yang berhubungan dengan keterampilan gerak kedua tangan, (b) Mampu menggerakan anggota tubuh yang berhubungan dengan jarijemari, (c) Mampu mengkoordinasi indera mata dengan aktivitas tangan, dan (d) Mampu mengendalikan emosi dalam beraktivitas motorik halus. Keterampilan motorik halus akan tumbuh dan berkembang dengan optimal jika distimulasi sejak anak usia dini. Untuk menstimulasi keterampilan motorik halus anak dilakukan melalui berbagai jenis kegiatan.

Berdasarkan hasil observasi yang dilakukan peneliti di Kelompok B Taman Kanak-kanak Islam Kemaraya Kendari, menunjukkan bahwa dari jumlah 14 anak hanya 5 anak didik atau sebesar $35,71 \%$ yang memiliki keterampilan motorik halus dengan kriteria Berkembang Sangat Baik (BSB) dan Berkembang Sesuai Harapan (BSH). Hal ini di sebabkan penggunaan media yang sangat terbatas dan tidak bervariasi akhirnya anak merasa bosan dengan pembelajaran.

Bertitik tolak pada paparan permasalahan tersebut, maka perlu dirancang suatu kegiatan pembelajaran yang menarik bagi anak untuk meningkatkan keterampilan motorik halus anak. Peneliti merasa perlu untuk menggunakan kegiatan menjahit dalam proses pembelajaran. Menjahit merupakan media visual yang efektif untuk belajar mengenai suatu konsep atau topik tertentu.

Darminta dalam Viliani, dkk (2014: 3) jahit adalah suatu pekerjaan mendekatkan dengan jarum atau benang jelujur atau meletakkan, menjepit, mengelem atau menyambung dengan jarum atau benang. Menjahit merupakan proses dalam menyatukan bagian-bagian kain yang telah digunting berdasarkan pola (Riny, $2010: 1$ ).

Hutauruk dalam Etika Halwa (2014: 2) menjahit adalah salah satu kegiatan yang dilakukan oleh anak usia dini sebagai upaya untuk mengembangkan motorik halus.

Menjahit merupakan salah satu kegiatan kreativitas untuk anak dengan menggunakan tangan dan berfungsi untuk melatih keterampilan motorik halus. Salah satu tujuan menjahit untuk anak usia dini adalah anak mampu mengkoordinasikan mata dan tangan untuk memasukan dan mengeluarkan sesuatu dari sebuah benda dengan berpikir.

Diharapkan dengan kegiatan menjahit maka motorik halus anak dapat berkembang

\section{METODE}

Jenis penelitian yang digunakan adalah Penelitian Tindakan Kelas (PTK). Penelitian ini dilaksanakan pada Kelompok B TK Islam Kemaraya Kendari. Penelitian dilaksanakan pada tanggal 5 sampai 15 Maret 2018 yaitu semester genap tahun akademik 2017/2018. 
Subjek dalam penelitian ini adalah guru dan anak didik yang berjumlah 14 orang yang terdiri atas 5 orang anak perempuan dan 9 orang anak laki-laki dengan rentang usia 5-6 tahun. Adapun faktor-faktor yang diteliti dan diamati dalam penelitian ini adalah sebagai berikut: faktor anak, faktor guru dan faktor hasil belajar anak.

Prosedur pelaksanaan dalam penelitian terdiri dari dua siklus dan masing-masing siklus memuat 4 (empat) kali pertemuan. Dalam setiap pertemuan terdiri dari perencanaan, tindakan, observasi dan refleksi.

Teknik pengumpulan data yang dilakukan dalam penelitian terdiri dari wawancara, observasi dan dokumentasi.

Pengolahan data dalam penelitian ini disesuaikan dengan teknik penilaian di TK Islam Kemaraya Kendari dengan menggunakan tanda sebagai berikut: $*=$ Belum Berkembang $(\mathrm{BB}), * *=$ Mulai Berkembang (MB), $* * *=$ Berkembang Sesuai Harapan (BSH), dan $* * * *=$ Berkembang Sangat Baik (BSB) (Depdiknas, 2004: 26).

Tabel 1. Kategori keberhasilan individual dan klasikal

\begin{tabular}{llcc}
\hline Individual & Klasikal & Kategori & Simbol \\
$3,50-4,00$ & $95 \%-100 \%$ & BSB & $* * * *$ \\
$2,50-3,49$ & $85 \%-94 \%$ & BSH & $* * *$ \\
$1,50-2,49$ & $75 \%-84 \%$ & MB & $* *$ \\
$0,01-1,49$ & $<75 \%$ & BB & $*$ \\
\hline
\end{tabular}

Untuk menentukan keberhasilan dan keefektifan penelitian, maka dirumuskan indikator kinerja dan indikator proses yang digunakan sebagai acuan keberhasilan. Adapun indikator kinerja dikatakan berhasil apabila mencapai minimal $85 \%$ anak memperoleh nilai BSH dan BSB.

\section{HASIL DAN PEMBAHASAN}

Sebelum memulai penelitian ini, peneliti terlebih dahulu melakukan pertemuan awal dengan Kepala TK Islam Kemaraya Kendari yaitu pada tanggal 28 Februari 2018, pertemuan ini bermaksud untuk menyampaikan tujuan dari peneliti yaitu mengadakan penelitian di TK Islam Kemaraya Kendari. Selanjutnya, Kepala TK mengarahkan peneliti untuk berdiskusi dengan guru Kelompok B3 yaitu Ibu Rijana dan sepakat untuk berkolaborasi dan menjadi observer dalam kegiatan ini. Selanjutnya peneliti melakukan observasi awal tanpa mengganggu proses pembelajaran.
Berdasarkan hasil observasi awal dan dilanjutkan dengan wawancara singkat dengan guru kelompok B3 di TK tersebut, bahwa dalam kegiatan pembelajaran berbagai pendekatan, metode dan media digunakan dan diterapkan pada proses pembelajaran anak usia dini namun kenyataannya di lapangan masih ditemukan bahwa dalam meningkatkan keterampilan motorik halus anak belum sepenuhnya dilakukan sehingga pada saat observasi/tes awal mengenai keterampilan motorik halus anak pada Kelompok $\mathrm{B}_{3}$ masih berada pada taraf Mulai Berkembang $(\mathrm{MB})$ atau dengan nilai $(* *)$.

Berdasarkan permasalahan yang dihadapi tersebut, maka peneliti berusaha merancang suatu bentuk kegiatan pembelajaran yang menarik dan menyenangkan bagi anak mengenai peningkatan keterampilan motorik halus anak yaitu melalui kegiatan menjahit.

Penelitian dilakukan dengan tindakan siklus I yang terdiri dari 4 kali pertemuan dan mengikuti empat tahapan kegiatan yaitu perencanaan, pelakanaan tindakan, observasi dan evaluasi, dan refleksi. Hal-hal yang dilakukan dalam tahap ini adalah menyiapkan RPPH dan RPPM, media yang dibutuhkan, lembar observasi anak dan guru serta alat evaluasi/penilaian.

Pelaksanaan tindakan siklus I pertemuan I dilaksanakan pada hari Senin, tanggal 5 Maret 2018 pada pukul 07.15 - 11.00 WITA dengan menggunakan tema tanaman, subtema macammacam buah dan tema spesifik buah apel. Kegiatan awal sebelum proses pembelajaran adalah guru dan anak masuk di dalam kelas dan duduk di atas karpet yang telah disediakan dan melakukan aktivitas seperti dzikir pagi, melafazkan surah pendek dalam Al-Qur'an, menyayikan syair keagamaan. Selanjutnya anakanak diarahkan untuk shalat dhuha berjamaah.

Kegiatan inti dalam proses pembelajaran yaitu memberikan gambaran tentang kegiatan yang akan dilakukan hari ini dan memberikan penjelasan mengenai tema. Guru telah menyiapkan media dan perlengkapan yang akan digunakan dalam proses pembelajaran, seperti gambar buah-buahan, pensil warna, pola gambar, gunting, benang dan pola jahitan.

Kemudian anak didik dibagi menjadi 2 kelompok dimana setiap kelompok beranggotakan 7 orang. Dalam setiap kelompok terdiri atas campuran anak laki-laki dan perempuan. Masing-masing kelompok diberi tugas yang berbeda. 
Anak didik yang berada pada kelompok pertama diberi tugas mewarnai gambar apel dan menggunting gambar yang telah diwarnai dan anak didik yang berada pada kelompok kedua diberi tugas menjahit mengikuti pola pada kertas yang telah disediakan. Tugas ini kemudian diroling pada dua kelompok tersebut sehingga semua anak didik mendapat giliran tugas yang sama yaitu menjahit mengikuti pola pada kertas. Setelah itu, menyanyikan beberapa lagu dan mengucapkan doa pulang. Guru melakukan refleksi kembali pada pembelajaran yang telah dilakukan.

Pelaksanaan tindakan siklus I pertemuan II dilaksanakan pada hari Selasa, tanggal 6 Maret 2018 pada pukul 07.15 - 11.00 wita dengan menggunakan tema tanaman, subtema macam-macam buah dan tema spesifik buah jeruk. Kegiatan awal sebelum proses pembelajaran adalah guru dan anak masuk didalam kelas dan duduk di atas karpet yang telah disediakan dan melakukan aktivitas seperti dzikir pagi, melafazkan surah pendek dalam AlQur'an menyayikan syair keagamaan. Selanjutnya anak-anak diarahkan untuk shalat dhuha berjamaah.

Kegiatan inti dalam proses pembelajaran yaitu memberikan gambaran tentang kegiatan yang akan dilakukan hari ini dan memberikan penjelasan mengenai tema. Guru telah menyiapkan media dan perlengkapan yang akan digunakan dalam proses pembelajaran, seperti gambar buah-buahan, pensil warna, pola gambar pada kain, gunting, buku tulis dan pensil.

Kemudian anak didik dibagi menjadi 2 kelompok dimana setiap kelompok beranggotakan 7 orang. Dalam setiap kelompok terdiri atas campuran anak laki-laki dan perempuan. Masing-masing kelompok diberi tugas yang berbeda.

Anak didik yang berada pada kelompok pertama diberi tugas mewarnai gambar jeruk dan menulis kata jeruk dan anak didik yang berada pada kelompok kedua diberi tugas menggunting pola gambar jeruk. Tugas ini kemudian diroling pada dua kelompok tersebut sehingga semua anak didik mendapat giliran tugas yang sama yaitu menggunting mengikuti pola. Setelah itu, menyanyikan beberapa lagu dan mengucapkan doa pulang. Guru melakukan refleksi kembali pada pembelajaran yang telah dilakukan.

Pelaksanaan tindakan siklus I pertemuan III dilaksanakan pada hari Rabu, tanggal 7 Maret 2018 pada pukul 07.15 - 11.00 wita dengan tema tanaman, sub tema macam-macam buah, dan tema spesifik buah pepaya. Kegiatan awal sebelum proses pembelajaran adalah guru dan anak masuk di dalam kelas dan duduk di atas karpet yang telah disediakan dan melakukan aktivitas seperti dzikir pagi, melafazkan surah pendek dalam Al-Qur'an menyayikan syair keagamaan. Selanjutnya anak-anak diarahkan untuk shalat dhuha berjamaah.

Kegiatan inti dalam proses pembelajaran yaitu memberikan gambaran tentang kegiatan yang akan dilakukan hari ini dan memberikan penjelasan mengenai tema dan langkah-langkah kegiatan yang akan dilakukan. Guru telah menyiapkan media dan perlengkapan yang akan digunakan dalam proses pembelajaran, seperti buah pepaya, pensil warna, pola buah pepaya pada kertas, gunting, benang, buku tulis dan pensil.

Kemudian anak didik dibagi menjadi 2 kelompok dimana setiap kelompok beranggotakan 7 orang. Dalam setiap kelompok terdiri atas campuran anak laki-laki dan perempuan. Masing-masing kelompok diberi tugas yang berbeda.

Anak didik yang berada pada kelompok pertama diberi tugas mewarnai gambar pepaya dan menulis kata pepaya dan anak didik yang berada pada kelompok kedua diberi tugas menjahit mengikuti pola pepaya. Tugas ini kemudian diroling pada dua kelompok tersebut sehingga semua anak didik mendapat giliran tugas yang sama yaitu menjahit mengikuti pola. Setelah itu, menyanyikan beberapa lagu dan mengucapkan doa pulang. Guru melakukan refleksi kembali pada pembelajaran yang telah dilakukan.

Pelaksanaan tindakan siklus I pertemuan IV dilaksanakan pada hari Kamis, tanggal 8 Maret 2018 pada pukul 07.15 - 11.00 wita dengan tema tanaman, sub tema macam-macam buah, dan tema spesifik buah mangga. Kegiatan awal sebelum proses pembelajaran adalah guru dan anak masuk di dalam kelas dan duduk di atas karpet yang telah disediakan dan melakukan aktivitas seperti dzikir pagi, melafazkan surah pendek dalam Al-Qur'an menyayikan syair keagamaan. Selanjutnya anak-anak diarahkan untuk shalat dhuha berjamaah.

Kegiatan inti dalam proses pembelajaran yaitu memberikan gambaran tentang kegiatan yang akan dilakukan hari ini dan memberikan penjelasan mengenai tema dan langkah-langkah kegiatan yang akan dilakukan. Guru telah menyiapkan media dan perlengkapan yang akan digunakan dalam proses pembelajaran, seperti buah mangga, pensil warna, pola buah mangga 
pada kain, gunting, benang, buku tulis dan pensil.

Kemudian anak didik dibagi menjadi 2 kelompok dimana setiap kelompok beranggotakan 7 orang. Dalam setiap kelompok terdiri atas campuran anak laki-laki dan perempuan. Masing-masing kelompok diberi tugas yang berbeda.

Anak didik yang berada pada kelompok pertama diberi tugas mewarnai gambar buah mangga dan menebalkan kata mangga dan anak didik yang berada pada kelompok kedua diberi tugas menjahit mengikuti pola mangga pada kain. Tugas ini kemudian diroling pada dua kelompok tersebut sehingga semua anak didik mendapat giliran tugas yang sama yaitu menjahit mengikuti pola mangga pada kain. Setelah itu, menyanyikan beberapa lagu dan mengucapkan doa pulang. Guru melakukan refleksi kembali pada pembelajaran yang telah dilakukan.

Selama proses pembelajaran berlangsung, guru sebagai observer mengamati jalannya pembelajaran dengan menggunakan lembar observasi untuk guru dan lembar observasi untuk anak. Kegiatan observasi dilakukan bersamaan dengan pelaksanaan tindakan untuk setiap pertemuan pada siklus I.

Hasil analisis observasi guru sesuai dengan lembar observasi sebanyak 16 aspek yang diamati harus dicapai oleh guru. Pada siklus I skor yang dicapai oleh guru dari 16 aspek hanya 11 aspek $(68,75 \%)$ diantaranya: 1) membuka kegiatan pembelajaran dengan mengucapkan salam, 2) guru membimbing anak untuk berdoa sebelum belajar, 3) Guru mermpersiapkan anak untuk belajar, 4) Guru menyiapkan media pembelajaran (buah-buahan), 5) Guru menjelaskan tujuan pembelajaran, 6) Guru mempersilahkan kepada anak untuk menarik benang dengan benar, 7) Guru mempersilahkan kepada anak untuk memasukkan ke lubang jahitan, 8) Guru mempersilahkan kepada anak untuk menjahit sesuai dengan pola jahitan jelujur, 9) Guru mempersilahkan kepada anak untuk menjahit mengikuti pola pada kain, 10) Guru memberikan motivasi, penguatan dan penghargaan pada anak, 11) Memberikan kesimpulan terhadap kegiatan yang dilakukan hari ini. Sedangkan yang tidak tercapai 5 aspek $(31,25 \%)$ diantaranya: 1) Guru memotivasi anak untuk rajin belajar, 2) Guru membagi anak ke dalam dua kelompok, 3) Guru memberi tugas kepada setiap kelompok, 4) Guru mengarahkan anak untuk merapikan perlengkapan yang telah digunakan, 5) Guru mengadakan tanya jawab tentang kegiatan yang dilakukan hari ini.

Untuk lebih jelasnya dapat dilihat pada diagram berikut:

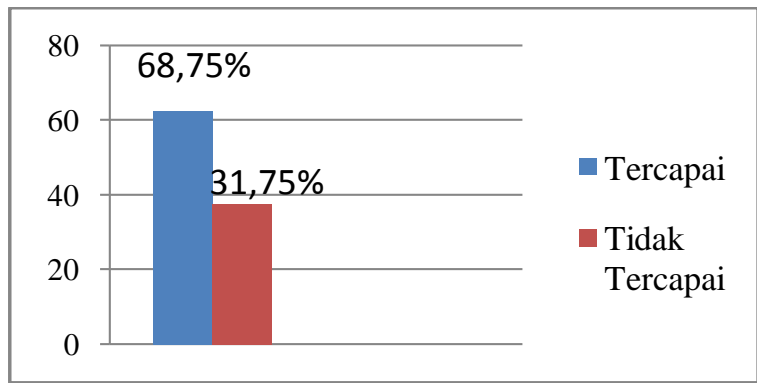

Gambar 1. Diagram Hasil Analisis Aktivitas Mengajar Guru Siklus I

Analisis aktivitas belajar anak pada siklus I skor yang dicapai anak adalah $60 \%$ atau 9 aspek dari 15 aspek yang meliputi: 1) Anak menjawab salam; 2) Berdo'a sebelum belajar; 3) Anak mempersiapkan diri untuk belajar; 4) Memperhatikan guru saat memperkenalkan media pembelajaran (buah-buahan); 5) Mendengarkan penjelasan guru mengenai tujuan pembelajaran; 6) Anak menarik benang dengan benar; 7) Anak menjahit mengikuti pola pada kain; 8) Melakukan tanya jawab dengan guru tentang kegiatan menjahit; 9) Mendengarkan nasehat dan kesimpulan terhadap kegiatan yang dilakukan hari ini. Sedangkan yang tidak tercapai 6 aspek (40\%) diantaranya: 1) Mendengarkan nasehat yang disampaikan guru; 2) Anak membentuk kelompok; 3) Anak antusias bertanya; 4) Anak memasukkan benang ke lubang jahitan; 5) Anak menjahit sesuai pola jahitan jelujur; 6) Anak merapikan perlengkapan yang telah digunakan. Untuk lebih jelasnya dapat dilihat pada diagram berikut:

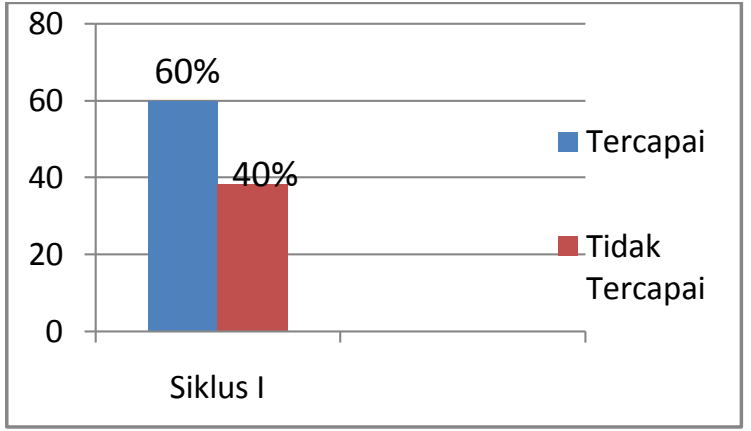

Gambar 2. Diagram Hasil Analisis Aktivitas Belajar Anak Didik Siklus I 
Tabel 2. Nilai Klasikal pada Siklus I

\begin{tabular}{lcc}
\hline Kategori & Jumlah Anak & Persentase \\
BSB & 2 & $14,29 \%$ \\
BSH & 7 & $50 \%$ \\
MB & 3 & $21,42 \%$ \\
BB & 2 & $14,29 \%$ \\
$\quad$ Jumlah & 14 & $100 \%$ \\
\hline
\end{tabular}

Berdasarkan Tabel 2, persentase keberhasilan secara klasikal anak didik yang mencapai kategori Berkembang Sangat Baik (BSB) sebanyak 2 anak didik (14,29\%), yang mencapai kategori Berkembang Sesuai Harapan (BSH) sebanyak 7 anak didik (50\%), yang mencapai kategori Mulai Berkembang (MB) sebanyak 3 anak didik $(21,42 \%)$, dan yang mencapai kategori Belum Berkembang (BB) sebanyak 2 anak didik (14,29\%). Dari hasil refleksi dengan obsever maka beberapa hal yang harus diperbaiki untuk pelaksanaan tindakan pada siklus II sebagai berikut:

1) Guru masih kurang dalam menyampaikan tujuan pembelajaran yang dilakukan. Solusi: Guru harus mampu mengelolah kelas dengan baik

2) Guru tidak mengorganisir waktu sesuai dengan apa yang telah direncanakan pada skenario pembelajaran. Solusi: Memberikan tugas tambahan kepada anak yang sudah bisa menjahit sehingga tidak mengganggu anak yang belum bisa menjahit

3) Guru masih canggung dalam melaksanakan kegiatan pembelajaran. Solusi: Guru harus lebih fokus dan percaya diri dalam menyampaikan materi pembelajaran.

4) Anak kurang mendengarkan penjelasan guru tentang langkah-langkah kegiatan yang akan dilakukan, sehingga membuat anak bingung ketika melakukan kegiatan secara mandiri

Berhubung hasil belajar anak belum mencapai indikator kinerja yang disepakati maka penelitian lanjut pada siklus II.

Pelaksanaan tindakan siklus II pertemuan I dilaksanakan pada hari Senin 12 Maret 2018 pada pukul 07.15 - 11.00 WITA dengan menggunakan tema tanaman, subtema macammacam sayuran dan tema spesifik wortel. Kegiatan awal sebelum proses pembelajaran adalah guru dan anak masuk di dalam kelas dan duduk di atas karpet yang telah disediakan dan melakukan aktivitas seperti dzikir pagi, melafazkan surah pendek dalam Al-Qur'an, menyayikan syair keagamaan. Selanjutnya anakanak diarahkan untuk shalat dhuha berjamaah.

Kegiatan inti dalam proses pembelajaran yaitu memberikan gambaran tentang kegiatan yang akan dilakukan hari ini dan memberikan penjelasan mengenai tema. Guru telah menyiapkan media dan perlengkapan yang akan digunakan dalam proses pembelajaran, seperti gambar sayuran, wortel, pensil warna, pola gambar, gunting, benang dan pola jahitan.

Kemudian anak didik dibagi menjadi 2 kelompok dimana setiap kelompok beranggotakan 7 orang. Dalam setiap kelompok terdiri atas campuran anak laki-laki dan perempuan. Masing-masing kelompok diberi tugas yang berbeda.

Anak didik yang berada pada kelompok pertama diberi tugas mewarnai gambar wortel dan menggunting gambar yang telah diwarnai dan anak didik yang berada pada kelompok kedua diberi tugas menjahit mengikuti pola wortel pada kertas yang telah disediakan. Tugas ini kemudian diroling pada dua kelompok tersebut sehingga semua anak didik mendapat giliran tugas yang sama yaitu menjahit mengikuti pola wortel. Setelah itu, menyanyikan beberapa lagu dan mengucapkan doa pulang. Guru melakukan refleksi kembali pada pembelajaran yang telah dilakukan.

Pelaksanaan tindakan siklus II pertemuan II dilaksanakan pada hari Selasa, tanggal 13 Maret 2018 pada pukul 07.15 - 11.00 wita dengan menggunakan tema tanaman, subtema macam-macam sayuran dan tema spesifik tomat. Kegiatan awal sebelum proses pembelajaran adalah guru dan anak masuk di dalam kelas dan duduk di atas karpet yang telah disediakan dan melakukan aktivitas seperti dzikir pagi, melafazkan surah pendek dalam Al-Qur'an menyayikan syair keagamaan. Selanjutnya anakanak diarahkan untuk shalat dhuha berjamaah.

Kegiatan inti dalam proses pembelajaran yaitu memberikan gambaran tentang kegiatan yang akan dilakukan hari ini dan memberikan penjelasan mengenai tema. Guru telah menyiapkan media dan perlengkapan yang akan digunakan dalam proses pembelajaran, seperti gambar sayuran, pensil warna, pola gambar pada kain, gunting, buku tulis dan pensil.

Kemudian anak didik dibagi menjadi 2 kelompok dimana setiap kelompok beranggotakan 7 orang. Dalam setiap kelompok terdiri atas campuran anak laki-laki dan perempuan. Masing-masing kelompok diberi tugas yang berbeda.

Anak didik yang berada pada kelompok pertama diberi tugas mewarnai gambar tomat dan menulis kata tomat dan anak didik yang berada pada kelompok kedua diberi tugas menggunting pola gambar tomat. Tugas ini 
kemudian diroling pada dua kelompok tersebut sehingga semua anak didik mendapat giliran tugas yang sama yaitu menggunting mengikuti pola. Setelah itu, menyanyikan beberapa lagu dan mengucapkan doa pulang. Guru melakukan refleksi kembali pada pembelajaran yang telah dilakukan.

Pelaksanaan tindakan siklus II pertemuan III dilaksanakan pada hari Rabu, tanggal 14 Maret 2018 pada pukul 07.15 - 11.00 wita dengan tema tanaman, sub tema macam-macam sayuran, dan tema spesifik labu. Kegiatan awal sebelum proses pembelajaran adalah guru dan anak masuk di dalam kelas dan duduk di atas karpet yang telah disediakan dan melakukan aktivitas seperti dzikir pagi, melafazkan surah pendek dalam Al-Qur'an menyayikan syair keagamaan. Selanjutnya anak-anak diarahkan untuk shalat dhuha berjamaah.

Kegiatan inti dalam proses pembelajaran yaitu memberikan gambaran tentang kegiatan yang akan dilakukan hari ini dan memberikan penjelasan mengenai tema dan langkah-langkah kegiatan yang akan dilakukan. Guru telah menyiapkan media dan perlengkapan yang akan digunakan dalam proses pembelajaran, seperti labu, pensil warna, pola labu pada kertas, gunting, benang, buku tulis dan pensil.

Kemudian anak didik dibagi menjadi 2 kelompok dimana setiap kelompok beranggotakan 7 orang. Dalam setiap kelompok terdiri atas campuran anak laki-laki dan perempuan. Masing-masing kelompok diberi tugas yang berbeda.

Anak didik yang berada pada kelompok pertama diberi tugas mewarnai gambar labu dan menulis kata labu dan anak didik yang berada pada kelompok kedua diberi tugas menjahit mengikuti pola labu. Tugas ini kemudian diroling pada dua kelompok tersebut sehingga semua anak didik mendapat giliran tugas yang sama yaitu menjahit mengikuti pola labu. Setelah itu, menyanyikan beberapa lagu dan mengucapkan doa pulang. Guru melakukan refleksi kembali pada pembelajaran yang telah dilakukan.

Pelaksanaan tindakan siklus II pertemuan IV dilaksanakan pada hari Kamis, tanggal 15 Maret 2018 pada pukul 07.15 - 11.00 wita dengan tema tanaman, sub tema macam-macam sayuran, dan tema spesifik buah terong. Kegiatan awal sebelum proses pembelajaran adalah guru dan anak masuk didalam kelas dan duduk di atas karpet yang telah disediakan dan melakukan aktivitas seperti dzikir pagi, melafazkan surah pendek dalam Al-Qur'an menyayikan syair keagamaan. Selanjutnya anakanak diarahkan untuk shalat dhuha berjamaah.

Kegiatan inti dalam proses pembelajaran yaitu memberikan gambaran tentang kegiatan yang akan dilakukan hari ini dan memberikan penjelasan mengenai tema dan langkah-langkah kegiatan yang akan dilakukan. Guru telah menyiapkan media dan perlengkapan yang akan digunakan dalam proses pembelajaran, seperti terong, pensil warna, pola terong pada kain, gunting, benang, buku tulis dan pensil.

Kemudian anak didik dibagi menjadi 2 kelompok dimana setiap kelompok beranggotakan 7 orang. Dalam setiap kelompok terdiri atas campuran anak laki-laki dan perempuan. Masing-masing kelompok diberi tugas yang berbeda.

Anak didik yang berada pada kelompok pertama diberi tugas mewarnai gambar terong dan menebalkan kata terong dan anak didik yang berada pada kelompok kedua diberi tugas menjahit mengikuti pola terong pada kain. Tugas ini kemudian diroling pada dua kelompok tersebut sehingga semua anak didik mendapat giliran tugas yang sama yaitu menjahit mengikuti pola terong pada kain. Setelah itu, menyanyikan beberapa lagu dan mengucapkan doa pulang. Guru melakukan refleksi kembali pada pembelajaran yang telah dilakukan.

Selama proses pembelajaran berlangsung, guru sebagai observer mengamati jalannya pembelajaran dengan menggunakn lembar observasi untuk guru dan lembar observasi untuk anak. Kegiatan observasi dilakukan bersamaan dengan pelaksanaan tindakan untuk setiap pertemuan pada siklus II.

Hasil analisis observasi guru sesuai dengan lembar observasi sebanyak 16 aspek yang diamati harus dicapai oleh guru. Pada siklus II skor yang dicapai oleh guru dari 16 aspek sebanyak 14 aspek $(87,5 \%)$ diantaranya:(1) Membuka kegiatan pembelajaran dengan mengucapkan salam; (2) Guru membimbing anak untuk berdoa sebelum belajar; (3) Guru mermpersiapkan anak untuk belajar; (4) Guru menyiapkan media pembelajaran; (5) Guru menjelaskan tujuan pembelajaran; (6) Guru membagi anak ke dalam dua kelompok; (7) Guru memberi tugas kepada setiap kelompok; (8) Guru mempersilahkan kepada anak untuk menarik benang dengan benar; (9) Guru mempersilahkan kepada anak untuk memasukkan ke lubang jahitan; (10) Guru mempersilahkan kepada anak untuk menjahit 
sesuai dengan pola jahitan jelujur; (11) Guru mempersilahkan kepada anak untuk menjahit sesuai dengan pola jahitan jelujur; (12) Guru mengadakan tanya jawab tentang kegiatan yang dilakukan hari ini; (13) Guru memberikan motivasi, penguatan dan penghargaan pada anak; (14) Memberikan kesimpulan terhadap kegiatan yang dilakukan hari ini. Sedangkan yang tidak tercapai 2 aspek $(12,5 \%)$ diantaranya: (1) Guru memotivasi anak untuk rajin belajar, dan (2) Guru mengarahkan anak untuk merapikan perlengkapan yang telah digunakan. Untuk lebih jelasnya dapat dilihat pada diagram berikut:

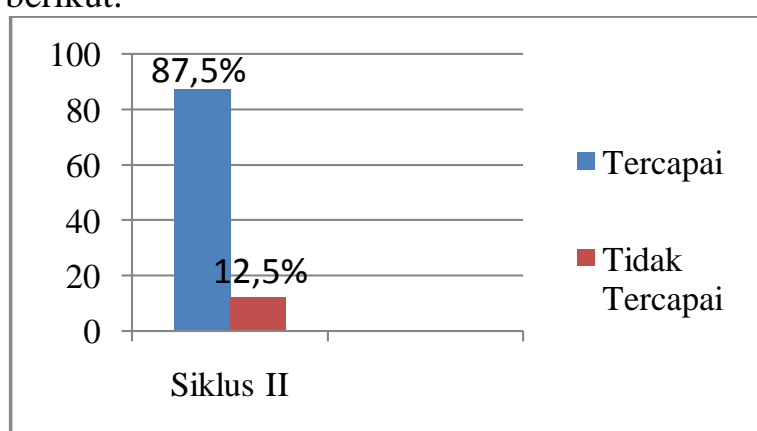

Gambar 3. Diagram Hasil Analisis Aktivitas Mengajar Guru Siklus II

Analisis hasil observasi anak didik sesuai dengan lembar observasi pada siklus II sebanyak 15 aspek yang diamati diharapkan tercapai, namun yang tercapai sebanyak 13 aspek $(86,67 \%)$ diantaranya: (1) Anak menjawab salam; (2) Berdo'a sebelum belajar; (3) Anak mempersiapkan diri untuk belajar; (4) Memperhatikan guru saat memperkenalkan media pembelajaran; (5) Mendengarkan penjelasan guru mengenai tujuan pembelajaran; (6) Anak membentuk kelompok; (7) Anak antusias bertanya; (8) Anak menarik benang dengan benar; (9) Anak memasukkan benang ke lubang jahitan; (10) Anak menjahit sesuai pola jahitan jelujur; (11) Anak menjahit mengikuti pola pada kain; (12) Melakukan tanya jawab dengan guru tentang kegiatan menjahit;(13). Mendengarkan nasehat dan kesimpulan terhadap kegiatan yang dilakukan hari ini. Sedangkan yang tidak tercapai 2 aspek (13,37\%) diantaranya: (1) Mendengarkan nasehat yang disampaikan guru; (2) Anak merapikan perlengkapan yang telah digunakan.

Untuk lebih jelasnya dapat dilihat pada diagram berikut:

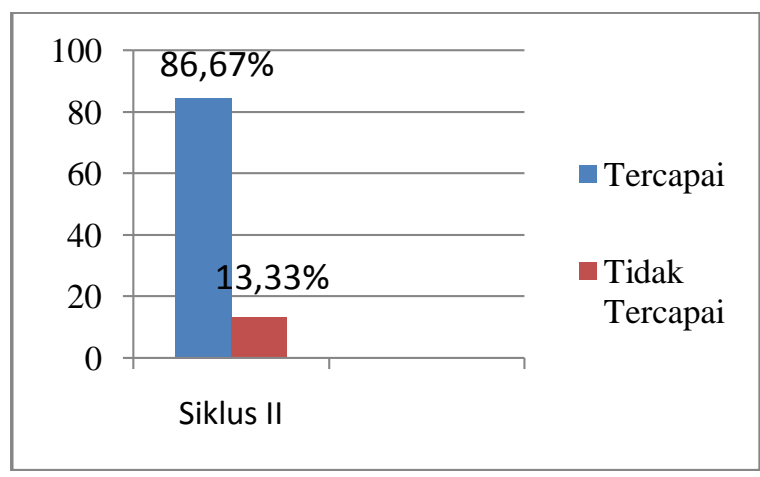

Gambar 4. Diagram Hasil Analisis Aktivitas Belajar Anak Didik Siklus II

Tabel 3. Nilai Klasikal pada Siklus II

\begin{tabular}{lcc|}
\hline \multicolumn{1}{c}{ Kategori } & Jumlah Anak & Persentase \\
BSB & 4 & $28,57 \%$ \\
BSH & 8 & $57,14 \%$ \\
MB & 2 & $14,29 \%$ \\
BB & 0 & 0 \\
Jumlah & 14 & $100 \%$ \\
\hline
\end{tabular}

Berdasarkan Tabel 3, persentase keberhasilan secara klasikal anak didik yang mencapai kategori Berkembang Sangat Baik (BSB) sebanyak 4 anak didik $(28,57 \%)$, yang mencapai kategori Berkembang Sesuai Harapan (BSH) sebanyak 8 anak didik $(57,14 \%)$ dan yang mencapai Mulai Berkembang (MB) sebanyak 2 anak didik (14,29\%). Selain itu dengan perolehan nilai sebesar $85,71 \%$ tersebut telah dicapai 12 orang anak didik, sehingga secara umum dapat dikatakan bahwa program kegiatan atau rangkaian pelaksanaan pembelajaran dalam meningkatkan keterampilan motorik halus anak melalui kegiatan menjahit pada kelompok B TK Islam Kemaraya kendari dipandang telah terselesaikan dan mencapai tingkat keberhasilan dan sesuai dengan indikator kinerja dan keberhasilan yang telah ditetapkan yaitu $85 \%$ anak memperoleh nilai $\mathrm{BSH}$ dan BSB, maka penelitian berhenti disiklus II.

\section{SIMPULAN DAN SARAN}

\section{Simpulan}

Berdasarkan hasil dan pembahasan dapat disimpulkan bahwa keterampilan motorik halus anak di Kelompok B TK Islam Kemaraya Kendari dapat ditingkatkan melalui kegiatan menjahit. Berdasarkan analisis data hasil observasi aktivitas mengajar guru pada siklus I diperoleh persentase ketercapaian sebesar $68,75 \%$, sedangkan aktivitas belajar anak didik diperoleh persentase ketercapaian sebesar $60 \%$. Pada siklus II, persentase ketercapaian aktivitas 
mengajar guru mengalami peningkatan menjadi $87,5 \%$, sedangkan persentase ketercapaian aktivitas belajar anak didik juga mengalami peningkatan menjadi $86,67 \%$.

Hasil belajar anak berupa peningkatan keterampilan motorik halus anak melalui kegiatan menjahit sebelum dilakukan tindakan sebesar 35,71\% anak memperoleh nilai BSB dan BSH kemudian meningkat pada siklus I sebesar $64,29 \%$ dan meningkat pada siklus II sebesar $85,71 \%$.

\section{Saran}

Setelah melaksanakan tindakan penelitian maka peneliti menyarankan hal-hal diantaranya dalam pelaksanaan pembelajaran maka hendaknya mempertimbangkan materi, media, dan strategi yang tepat untuk anak didik dan guru dituntut untuk selalu kreatif dan inovatif dalam mengunakan kegiatan-kegiatan yang dapat meningkatkan potensi anak didik

\section{DAFTAR PUSTAKA}

Depdiknas. 2004. Pedoman Penilaian di Taman Kanak-Kanak. Jakarta: Depdiknas.

.. 2008. Pengembangan Kemampuan Motorik Halus di Taman Kanak-Kanak. Jakarta: direktorat jendral manajemen pendidikan dasar dan menengah, direktorat pembinaan TK dan SD.

Direktorat PAUD. 2004. Apa, Mengapa, dan Siapa yang Bertanggung Jawab terhadap Program Pendidikan Anak Usia Dini?. Jakarta: Depdiknas.

Djamaris, Martini. 2003. Perkembangan dan Pengembangan Anak Usia Taman Kanak-Kanak. Jakarta: UNJ

Fanggideaj, Lenny. 1995. Kamus Pendidikan. Jakarta: Restu Agung.

Halwa, Etika. 2014. Pengaruh Kegiatan Menjahit Terhadap Kemampuan Motorik Halus Anak Kelompok A Di TK Pejajaran. [Online]

Kartini Kartono. 1998. Psikologi Anak. Bandung: Alumni.

Riny. 2010. Pengertian menjahit. Online: http:// kemejamurah.woorpress.com/category/p engertian-menjahit/. Diakses 15 november 2017.

Samsu, Y.,\& Nani, M. S. 2016. Perkembangan Peserta Didik. Jakarta: Rajawali Pers.
Sumantri. 2005. Model Pengembangan Keterampilan Motorik Anak Usia Dini. Jakarta: Depdiknas.

Sunardi \& Sunaryo. 2007. Intervensi Dini Anak Berkebutuhan Khusus. Jakarta: Departem en Pendidikan Nasional Jenderal Pendidikan Tinggi Direktorat Ketenagaan.

Viliani, Rosi Pusparina.et al. 2014. Peningkatan Keterampilan Motorik Halus Melalui Kegiatan Menjahit pada Anak kelas B TK Ngembak 1 Kecamatan Purwodadi Kabupaten Grobogan[Online]. Tersedia: http://www.ejournal.fkip.uns.ac.id/inde. php/paud/article/view/6883. 